\title{
HUBUNGAN MOTIVASI DAN DISIPLIN BELAJAR DENGAN HASIL BELAJAR HAFALAN AL QUR'AN
}

\author{
Habibi, Suradika, dan Ansharullah \\ Magister Teknologi Pendidikan Universitas Muhammadiyah Jakarta \\ habibabduh@gmail.com \\ agus.suradika@umj.ac.id \\ step_ansharullah@yahoo.com
}

\begin{abstract}
The purpose of this study was to determine the relationship between motivation and learning discipline and learning outcomes of learning to memorizing the Qur'an. This research includes a quantitative correlational, the data collection techniques was used a questioners and tests, used in descriptive quantitative analysis, with a sample of 46 students of class VIII and IX of SMP Khalifa IMS (Khalifa IMS Secondary). The results of this study (1) there is a significant relationship between student learning motivation and learning outcomes of learning to memorizing the Qur'an, (2) there is a significant relationship between student learning discipline and learning outcomes of learning to memorizing the Qur'an, (3) there is a very significant relationship between learning motivation and student learning discipline with learning outcomes in memorizing the Al-Qur 'an.
\end{abstract}

Keywords: Learning Motivation, Learning Discipline, Learning Outcomes

\section{ABSTRAK}

Penelitian ini bertujuan untuk mengetahui hubungan motivasi dan disiplin belajar dengan hasil belajar hafalan Al Qur'an. Penelitian ini termasuk penelitian kuantitatif korelasional dengan teknik survey menggunakan analisis deskriptif kuantitatif, sampel dalam penelitian sebanyak 46 siswa kelas VIII dan IX SMP Khalifa IMS Pondok Aren. Hasil penelitian ini menunjukkan bahwa: (1) terdapat hubungan yang signifikan antara motivasi belajar dengan hasil belajar hafalan Al Qur'an, (2) terdapat hubungan signifikan antara disiplin belajar dengan hasil belajar hafalan Al Qur'an, (3) terdapat hubungan yang signifikan antara motivasi belajar dan disiplin belajar dengan hasil belajar hafalan Al Qur'an.

Kata kunci: Motivasi Belajar, Disiplin Belajar, Hasil Belajar

\section{PENDAHULUAN}

Undang-undang Sitem Pendidikan Nasional (UU SISDIKNAS) No 20/2003 Pasal 1 , menyatakan bahwa pendidikan adalah usaha sadar dan terencana untuk mewujudkan suasana belajar dan proses pembelajaran agar siswa secara aktif mengembangkan potensi dirinya untuk memiliki kekuatan spiritual keagamaan, pengenalan diri, kepribadian, kecerdasan, akhlak mulia, serta keterampilan yang diperlukan dirinya, masyarakat, bangsa dan negara. Hasil belajar dalam suatu lembaga pendidikan merupakan indikator pencapaian nilai siswa. Begitu pula hasil belajar hafalan $\mathrm{Al}$ Qur'an yang Allah SWT firmankan bahwa Al Qur'an mudah untuk dipelajari sebagaimana
firman-Nya dalam surah Al Qomar ayat 17, 22, 32, 40 berikut:

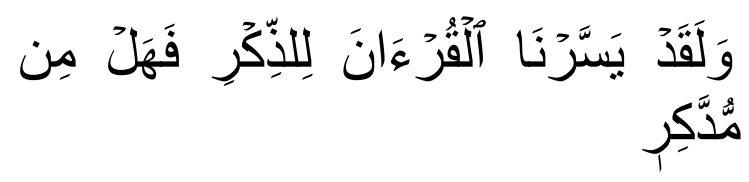

Artinya: dan sungguh telah kami mudahkan Al Qur'an untuk diingat (pelajari), maka apakah ada yang mau mempelajarinya? (Qs. Al Qomar 17, 22,32,40).

Ibnu Katsir (2005:483) menafsirkan ayat ini bahwa Allah SWT telah memudahkan lafadz dan makna Al Qur'an, maka adakah orang yang mengambil pelajaran dari Al Qur'an yang mudah untuk dihafal dan dipahami maknanya? Sudjana (2009:3) mendefinisikan hasil belajar siswa pada hakikatnya adalah perubahan 
tingkah laku sebagai hasil belajar dalam pengertian yang lebih luas mencakup bidang kognitif, afektif, dan psikomotorik. Slameto (2010:54) menyatakan hasil belajar siswa dapat dipengaruhi oleh faktor internal maupun eksternal. Di antara faktor tersebut adalah motivasi dan disiplin belajar siswa. Motivasi belajar pada saat pembelajaran diharapkan dapat mendorong siswa lebih baik dalam mengikuti proses pembelajaran di kelas maupun di luar kelas seperti di rumah, agar dapat berhasil dalam belajar. Sardiman (2014:73) mengartikan motivasi berasal dari kata motif yang berarti daya penggerak yang telah aktif, maksudnya motif dapat dikatakan sebagai daya untuk menggerakkan sesuatu baik dari dalam dan diluar subjek untuk melakukan aktifitas tertentu, demi mencapai suatu tujuan. Demikian pula halnya disiplin diharapkan dapat mengatur tingkah laku siswa agar dapat disiplin sesuai dengan peraturan yang diterapkan. Tanpa adanya sikap disiplin maka kesadaran untuk membiasakan aktivitas belajar dengan aturan yang ada tidak akan terjadi, sehingga dapat menyebabkan hasil belajar tidak mencapai hasil yang maksimal. Prijodarminto dalam Tu'u (2008:31) menyatakan bahwa disiplin adalah suatu kondisi yang tercipta dan terbentuk melalui proses dari serangkaian perilaku yang menunjukkan nilai ketaatan, kepatuhan, kesetiaan keteraturan atau ketertiban. Berdasarkan observasi di lapangan diperoleh data bahwa masih ada siswa yang belum siap ketika diminta menyetorkan hafalan, bahkan beralasan untuk tidak menyetorkan hafalan. Pada saat talaqqi (belajar secara langsung berhadapan dengan guru) ayat yang akan dihafalkan masih ada siswa yang mengobrol dengan temannya, tidak memperhatikan arahan guru dan tidak membawa mushaf atau juz 'Amma. Hal ini menunjukkan bahwa motvasi belajar siswa masih belum maksimal. Dari sisi kedisiplinan masih ada siswa yang terlambat menyetorkan hafalan, terlambat datang ke sekolah dan terlambat masuk kelas. Adapun pembelajaran hafalan Al Qur'an di SMP Khalifa IMS adalah pelajaran wajib yang harus dilakukan oleh siswa, sehingga hal hal tersebut diduga memberikan efek terhadap hasil belajar siswa yang belum maksimal yang ditunjukan oleh masih ada siswa yang belum mencapai Kriteria Ketuntasan Minimal (KKM) yaitu sekitar 75 untuk pelajaran hafalan Al Qur'an. Berdasarkan permasalahan yang diungkapkan di atas, penulis tertarik melakukan penelitian terkait hubungan motivasi, disiplin belajar siswa dan hasil belajar hafalan Al Qur'an.

\section{KAJIAN LITERATUR}

\section{Hasil Belajar Hafalan Al Qur'an}

Hasil belajar merupakan perubahan kemampuan siswa yang diperoleh setelah proses pembelajaran. Menurut Dimyati dan Mudjiono (2006:3-4) hasil belajar merupakan hasil suatu interaksi tindak belajar dan mengajar yang dilakukan oleh dua sisi yaitu sisi pendidik maupun sisi siswa. Lebih lanjut Bloom sebagaimana dikutip Dimyati dan Mudjiono (2006:205) mengemukakan taxonomy of education objectives, di mana tujuan pendidikan dibagi menjadi tiga ranah, yaitu kognitif, afektif, dan psikomotorik. Selanjutnya Sudjana (2009:3) mendefinisikan bahwa hasil belajar siswa pada hakikatnya adalah perubahan tingkah laku sebagai hasil belajar. Dalam pengertian yang lebih luas mencakup bidang kognitif, afektif, dan psikomotorik. Faktor yang mempengaruhi hasil belajar siswa dapat dari luar dirinya maupun dari dalam dirinya, sebagaimana dikemukakan oleh Slameto (2010:54) yang menyatakan bahwa hasil belajar siswa dapat dipengaruhi oleh faktor internal maupun eksternal.

\section{Hafalan Al Qur'an}

Dalam kamus KBBI hafal artinya adalah telah masuk dalam ingatan (tentang pelajaran): saya sudah mempelajari dan juga isinya atau dapat mengucapkan di luar kepala (tanpa melihat buku atau catatan lain. Selanjutnya dalam kamus Oxford (926) menghafal berarti memorize (to learn carefully so that you can remember it exactly). Selanjutnya di dalam Cambridge dictionary mengahafal berarti to learn (something) so well that one can remember all of it without looking. Secara etimologi Hasbi (2002:3) menyatakan bahwa perbuatan menghafal berasal dari kata dasar hafal, dalam bahasa Arab di sebut al-hifzu dan orang yang hafal di sebut al-hafiz yang memiliki arti ingat. Maka kata menghafal juga dapat diartikan dengan mengingat. Sedangkan secara terminologi, menghafal mempunyai arti sebagai tindakan yang berusaha meresapkan ke dalam pikiran agar selalu ingat. Menghafal adalah suatu aktivitas menanamkan suatu materi ke dalam ingatan, sehingga nantinya 
akan dapat diingat kembali secara harfiyah, sesuai dengan materi yang asli.

\section{Al Qur'san}

Al Qur'an berasal dari bahasa arab yaitu

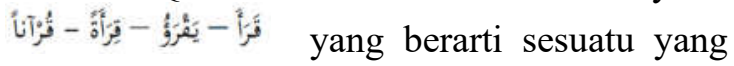
dibaca. Arti ini mempunyai makna anjuran kepada umat Islam untuk membaca Alquran. Al

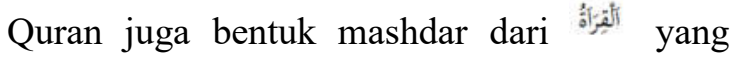
berarti menghimpun dan mengumpulkan. Dikatakan demikian sebab seolah-olah Alquran menghimpun beberapa huruf, kata, dan kalimat secara tertib sehingga tersusun rapi dan benar. Shihab (1996:3) menyatakan Al Qur'an secara harfiyah berarti bacaan yang sempurna. Al Qur'an merupakan suatu nama pilihan Allah yang tepat, karena tiada suatu bacaanpun sejak manusia mengenal tulis baca lima ribu tahun yang lalu yang dapat menandingi Al quran, bacaan sempurna lagi mulia.

Adapun Al Qur'an menurut istilah (As Shobuni1985:8) berarti,

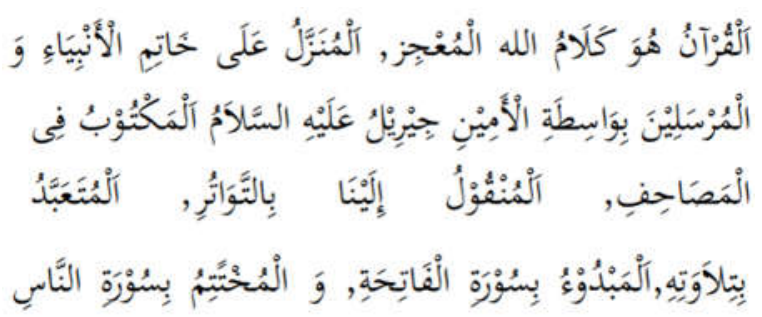

Artinya: Al Qur'an adalah kalam Allah SWT yang mengandung mu'jizat, yang diturunkan kepada Nabi Muhammad SAW, dengan perantara malaikat Jibril as, yang tertulis di dalam mushaf, disampaikan kepada kita dengan jalan mutawatir, membacanya bernilai ibadah, yang diawali dengan surah $\mathrm{Al}$ Fatihah dan diakhiri dengan surah An Nas. Lebih lanjut Anshor (2013:18-19) menyatakan, setidaknya ada 5 faktor penting yang menjadi karakteristik Al Qur'an yaitu: (a) firman Allah SWT, (b) hanya diberikan kepada Nabi Muhammad SAW, (c) Mu'jizat, (d) diriwayatkan secara mutawatir, dan (e) membacanya dicatat sebagai amal ibadah. Berdasarkan uraian di atas dapat simpulkan bahwa hasil belajar terjadi apabila kegiatan belajar disertai oleh adanya perubahan baik di ranah kognitif, afektif, maupun psikomotorik. Hasil belajar seseorang dapat dipengaruhi atau ditentukan oleh faktor internal maupun faktor ekternal. Sedangkan menghafal dapat diartikan sebagai aktivitas memindahkan materi (ayat $\mathrm{Al}$
Qur'an) ke dalam ingatan sehingga dapat diingat dan dilafazkan kembali secara harfiah sesuai dengan aslinya. Metode menghafal seseorang pada umumnya dapat dilakukan dengan (a) kitabah, (b) sima 'i,/tasmi' (c) bin nazhar, (d) talaqqi, (e) takrir/muroja'ah. Di SMP Khalifa IMS metode mengahafal yang digunakan adalah semua metode yang disebutkan di atas. Metode menghafal tersebut dapat diterapkan dengan cara (a) mengulang ulang ayat yang akan dihafal (b) menggunakan satu jenis mushaf selama menghafal, (c) focus pada ayat yang sedang dihafal, dan tidak beralih ke ayat selanjutnya sebelum hafal, (d) mengafal urutan ayat yang dihafal dalam satu kesatuan, (e) memperhatikan ayat yang serupa, dan (f) menyetorkan hafalan kepada pembibing.

Adapaun cara menjaga ayat yang sudah dihafal adalah dengan melakukan muroja'ah (mengulang ulang) sampai mutqin baik dengan cara melihat mushaf (bin nadzar) ataupun dengan tanpa melihat mushaf (bil ghoib). Selanjutnya indikator hasil hafalan Al Qur'an adalah (a) dapat membaca dengan lancar, (b) dapat membaca dengan tajwid yang benar, (c) dapat membaca dengan makhroj huruf yang fasih, (d) dapat membaca tanpa melihat mushaf.

\section{Motivasi belajar}

Motivasi yang terdapat dalam diri seseorang menentukan aktivitas belajar seharihari, hal ini karena motivasi dapat mengaktifkan dan menggerakkan sikap dan perilaku individu untuk belajar dan menyelesaikan tugas belajar. Sardiman (2014:73) menyatakan bahwa motivasi berasal dari kata motif yang berarti daya penggerak yang telah aktif, maksudnya motif dapat dikatakan sebagai daya untuk menggerakkan sesuatu baik dari dalam dan di luar subjek untuk melakukan aktifitas tertentu, demi mencapai suatu tujuan. Selanjutnya Mc Donald dikutip oleh Hamalik (2003:158) menyatakan bahwa "Motivation is an energy change within the person characterized by affective arousal and anticipatory goal reaction". Lebih lanjut Murphy dan Alexander dalam Kathryn dan Jere (2014:2) menyatakan bahwa "Motivation is a theoretical construct used to explain the initiation, direction, intensity, persistence, and quality of behavior, especially goal-directed behavior". Eva (2012:160-161) menyatakan bahwa beberapa ahli menuturkan, motivasi mempengaruhi pembelajaran melalui proses 
berikut: (a) mengarahkan perilaku ke tujuan tertentu, (b) meningkatkan usaha dan energi, (c) meningkatkan prakarsa dan kegigihan terhadap berbagai aktivitas, (d) motivasi mempengaruhi proses kognitif, (e) mentukan konsekeensi mana yang memberi penguatan dan menghukum, dan (f) meningkatkan perfroma. Selanjutnya pengertian belajar menurut Hamalik (2003:27) adalah modifikasi atau memperkuat kelakuan melalui pengalaman "learning is defined as the modification or strengthening of behavior through experiencing". Adapun motivasi belajar menurut Rusmiasih (2013) adalah kondisi psikologis yang mendorong seseorang untuk belajar. Lebih lanjut Sardiman (2014:85-86) menyatakan fungsi motivasi belajar adalah sebagai pendorong usaha dan pencapaian prestasi. Dari pemaparan beberapa pedapat di atas dapat di simpulkan bahwa Motivasi belajar adalah dorongan atau rangsangan pada diri siswa untuk melakukan suatu kegiatan belajar dengan tujuan tertentu yang diinginkan oleh siswa tersebut. Berdasarkan teori psikologi kebutuhan (needs) Maslow sebagaimana dikutip Sardiman (2001:78), manusia memiliki kebutuhan (a) fisiologis, (b) perasaan aman dan tentram, (c) rasa memiliki dan rasa cinta, (d) penghargaan dan penghormatan, dan (e) aktualisai diri. Maka dapat disimpulkan bahwa motivasi berkaitan dengan bagaimana manusia dapatn mengaktualisasikan dirinya melalui kegiatan belajar karena adanya kebutuhan untuk meningkatkan hasil belajar. Untuk mengukur tingkat motivasi belajar siswa diperlukan adanya indikator motivasi. Menurut Stephen, Thomas dan Joan (2000:333) ada dua jenis motivasi yaitu intrinsic motivation and extrinsic motivation. Intrinsic motivation is the desire of students themselves to learn, without the need for external inducements. Lebih rinci lagi Hamzah B. Uno (2012: 13) mengemukakan bahwa indikator motivasi belajar dapat diklasifikasikan sebagai berikut: 1. Motivasi dari dalam (Internal), yaitu: a. adanya hasrat dan keinginan berhasil, $b$. adanya dorongan dan kebutuhan dalam belajar, dan c. adanya harapan dan cita-cita masa depan. 2. Motivasi dari luar (eksternal), yaitu: a. adanya pengahargaan dalam belajar, b. adanya kegiatan yang menarik dalam belajar, dan c. danya lingkungan belajar yang kondusif. Dalam penlitian ini indikator motivasi belajar yang digunakan adalah (a) ketekunan dalam belajar, (b) keuletan dalam menghadapi kesulitan, (c) kesenangan untuk mandiri ketika belajar, dan (d) adanya harapan dan cita -cita masa depan.

\section{Disiplin Belajar}

Seorang siswa dalam menjalankan aktivitas belajar perlu adanya kedisiplinan, tanpa adanya suatu kedisiplinan maka kesadaran untuk membiasakan aktivitas belajar dengan aturan yang ada tidak akan terjadi, akibatnya pembelajaran tidak akan mencapai hasil yang maksimal. Disiplin dalam KBBI diartikan sebagai tata tertib (di sekolah, kemiliteran, dan sebagainya); ketaatan (kepatuhan) kepada peraturan (tata tertib dan sebagainya) bidang studi yang memiliki objek, sistem dan metode tertentu. Sedangkan menurut Yunus dan Bakri (1991:36) disiplin adalah kekuatan yang ditanamkan oleh para pendidik untuk menanamkan dalam jiwa tentang tingkah laku dalam pribadi murid dan bentuk kebiasaan dalam diri mereka, tunduk dan patuh dengan sebenar-benarnya pada aturan-aturan yang sesuai dengan prinsip pendidikan yang sesungguhnya yaitu inti yang dijalankan pada setiap aktivitas sekolah. Selanjutnya Prijodarminto dalam Tu'u (2008:31) menyatakan disiplin sebagai suatu kondisi yang tercipta dan terbentuk melalui proses dari serangkaian perilaku yang menunjukkan nilai ketaatan, kepatuhan, kesetiaan keteraturan atau ketertiban. Lebih lanjut Sanjaya (2005:9) menyatakan bahwa disiplin bejalar adalah hal yang sangatlah diperlukan bagi setiap siswa. Dengan adanya disiplin belajar, tujuan pendidikan akan lebih mudah tercapai. Adapun fungsi disiplin menurut Tu'u (2008:38-43) antara lain: (a) menata kehidupan bersama, (b) membangun keperibadian, (c) melatih keperibadian yang baik, dan (d) menciptakan lingkungan belajar yang kondusif. Dari berbagai pendapat di atas dapat dikemukakan bahwa disiplin belajar adalah suatu sikap dan tingkah laku seorang siswa yang menunjukkan sikap ketaatan dan kepatuhan dalam melakukan aktivitas belajar atau pembelajaran baik di rumah, sekolah dan lingkungan masyarakat yang tumbuh di dalam diri siswa tersebut. Untuk mengukur disiplin belajar siswa diperlukan adanya indikator berikut: (a) disiplin waktu, (b) disiplin perbuatan, (c) disiplin siswa selama pembelajaran berlangsung, (d) disiplin siswa pada saat mengerjakan dan mengumpulkan tugas, dan (e) disiplin siswa pada saat menggunakan fasilitas sekolah. Berdasarkan 
kajian teori yang telah dikemukan di atas dapat di susun kerangka berpikir sebagai berikut: motivasi dan disiplin belajar adalah hal yang sangat penting harus dimiliki siswa dalam proses pembelajaran, dengan motivasi dan disiplin belajar yang baik siswa dapat mencapai tujuan belajar tertentu secara optimal. Indikator motivasi dan disiplin belajar siswa yang digunakan untuk instrumen penelitian hubungan ini dapat di lihat pada tabel berikut:

\section{METODE PENELITIAN}

Penelitian ini dilaksanakan di SMP Khalifa IMS Pondok Aren Tangerang Selatan Banten. Penelitian dilakukan pada semester

Tabel 1 Indikator Motivasi dan Disiplin Belajar

\begin{tabular}{|c|c|c|}
\hline No & Variabel & Indikator \\
\hline \multirow{4}{*}{1} & \multirow{4}{*}{$\begin{array}{l}\text { Motivasi } \\
\text { Belajar }\end{array}$} & $\begin{array}{l}\text { 1.1. Ketekunan dalam } \\
\text { belajar }\end{array}$ \\
\hline & & $\begin{array}{l}\text { 1.2. Keulean menghadapi } \\
\text { kesulitan }\end{array}$ \\
\hline & & $\begin{array}{l}\text { 1.3. Kesenangan untuk } \\
\text { mandiri ketika belajar }\end{array}$ \\
\hline & & $\begin{array}{l}\text { 1.4. Adanya harapan dan } \\
\text { cita cita }\end{array}$ \\
\hline \multirow{5}{*}{2} & \multirow{5}{*}{$\begin{array}{l}\text { Disiplin } \\
\text { Belajar }\end{array}$} & 2.1. Disiplin waktu \\
\hline & & 2.2. Disiplin perbuatan \\
\hline & & $\begin{array}{l}\text { 2.3. Disiplin siswa selama } \\
\text { pembelajaran } \\
\text { berlansgung }\end{array}$ \\
\hline & & $\begin{array}{l}\text { 2.4. Disiplin siswa saat } \\
\text { mengerjakan tugas dan } \\
\text { mengumpulkan tugas }\end{array}$ \\
\hline & & $\begin{array}{l}\text { 2.5. Disiplin siswa saat } \\
\text { menggunakan fasilitas } \\
\text { belajar }\end{array}$ \\
\hline
\end{tabular}

ganjil tahun ajaran 2020/2021 yaitu pada bulan Agustus 2020 sampai dengan Desember 2021. Populasi dalam penelitian ini adalah siswa kelas VIII dan IX SMP Khalifa IMS yang berjumlah 46 orang tahun akademik 2020/2021. Sampel dalam penelitian ini sebanyak 46 orang diambil dari siswa kelas VIII dan IX SMP Khalifa IMS. Mengikuti penelitian Sugiyono (2012:104) jika jumlah populasinya kurang dari 100 orang, maka jumlah sampelnya diambil secara keseluruhan, tetapi jika populasinya lebih besar dari 100 orang, maka bisa diambil $10-15 \%$ atau $20-25 \%$ dari jumlah populasinya. Penelitian ini merupakan penelitian kuantitatif asosiatif dan menggunakan pendekatan korelasional. Pendekatan ini digunakan untuk mencari hubungan antara variabel bebas (X) dengan variabel terikat (Y). Pengumpulan data dalam penelitian ini menggunakan kuisioner dates, Endang (2011:28) mengatakan kuisioner atau angket merupakan alat pengumpulan data yang memuat sejumlah pertanyaan atau pernyataan yang harus dijawab oleh subjek penelitian. Sebagaimana test adalah alat ukur untuk mengetahui tercapainya atau tidaknya tujuan pembelajaran, atau untuk mengukur hasil belajar, data yang akan digunakan yaitu: (a) motivasi belajar dan (b) disiplin belajar. Selanjutnya data yang telah dikumpulkan dilakukan uji validitas dan reliabilitas. Valid menurut Sugiyono (2015:348) "berarti instrumen tersebut dapat digunakan untuk mengukur apa yang hendak diukur". Dengan membadingkan rhitung $>$ rtabel dengan taraf signifikasnsi $\alpha=0,05$ maka dari 30 pernyataan pada variabel motivasi belajar didapatkan 27 pernyataan yang valid dan dari 28 pernyataan pada variabel disiplin belajar didapatkan 26 pernyataan yang valid, pernyataan yang valid selanjutnya digunakan untuk mengambil data penelitian ini dengan menggunakan skala likert (rentang 1-4). Selanjutnya data yang terkumpul, akan dianalisis dengan menggunakan statistik deskriptif dan kuantitatif, yaitu untuk memperoleh gambaran karakteristik penyebaran skor pada setiap variabel yang diteliti dengan menghitung rata-rata, simpangan baku, median dan modus. Ningsih (2011:38) mengatakan analisis data secara deskriptif digunakan untuk mendeskripsikan data penelitian apa adanya dan tidak digunakan untuk mendapatkan kesimpulan statistik. Selanjutnya statistic induktif digunakan untuk menguji hipotesis yang telah dikemukakan. Semua data tersebut diuji dengan menggunakan bantuan software SPSS dan dilakukan pada taraf signifikansi $\alpha=0,05$. Hipotesis statistik: Ho: $\rho y 1 \leq 0 \mathrm{H} 1$ : $\rho y 1>0$

\section{Hasil dan pembahasan}

Berdasarkan hasil perhitungan statistik deskriptif motivasi belajar mempunyai nilai rata-rata sebesar 82,07 dengan nilai simpangan 
baku 5,71, median sebesar 82 dan modus sebesar 82 dan disiplin belajar mempunyai nilai rata-rata sebesar 76,80 dengan nilai simpangan baku 5,12, median sebesar 77 dan modus sebesar 78 .

\section{Pengujian persyaratan analisis}

\section{1). Uji Normalitas Galat Taksiran Regresi}

Uji normalitas menggunakan uji Lilliefors yaitu dengan melihat L hitung yang diperoleh nilai mutlak selisih Fzi - Szi yang terbesar, kemudian membandingkan dengan $\mathrm{L}$ tabel nilai kritis Uji Lilliefors pada taraf signifikansi 0,05 , diperoleh data berdistribusi normal. Nilai uji liliefors pada motivasi belajar Lhitung $0,093<$ Ltabel 0,131 dan disiplin belajar Lhitung $0,115<$ Ltabel 0,131 maka kedua variabel berdistribusi normal.

\section{2). Uji Signifikansi dan Linearitas Regresi}

Untuk mengetahui signifikansi hubungan antar variabel bebas dengan variabel terikat perlu dilakukan uji $\mathrm{F}$ dan uji linearitas dalam tabel ANOVA. Dikatakan signifikan apabila F hitung $>$ F tabel. Data hasil uji F pada variabel motivasi belajar dengan hasil belajar pada tingkat sinifikansi di peroleh $\mathrm{F}$ hitung $27,481>$ F tabel 4,06 pada $\alpha=0,05$ dan hasil uji linearitas di peroleh Fhitung 0,741 $\mathrm{F}$ tabel 4,06 pada $\alpha=0,05$ dan hasil uji linearitas diperoleh $\mathrm{F}$ hitung0,466

\section{3). Uji Multikolinearitas}

Menurut Ghozali (2011: 105-106) uji multikolinieritas bertujuan untuk menguji apakah model regresi ditemukan adanya korelasi antar variabel bebas (independent). Uji ini dilakukan bertujuan untuk mencegah adanya korelasi yang tinggi antar variable independent. Untuk menguji multikolinieritas dengan cara melihat nilai VIF masing-masing variabel independen, jika nilai $\mathrm{VIF}<10$, maka dapat disimpulkan data bebas dari gejala multikolinieritas. Hasil uji multikolineritas diperoleh motivasi belajar (X1) sebesar 1,843 (VIF < 10), nilai VIF disiplin belajar (X2) sebesar 1,843 (VIF < 10).

Dengan demikian dapat disimpulkan bahwa tidak ada multikolonieritas antar variabel independen Motivasi Belajar (X1), Disiplin Belajar (X2) dalam model regresi.

\section{4). Uji Heteroskedastisitas}

Menurut (Ghozali 2016:134) model yang baik adalah yang tidak terjadi heteroskedastisitas. Uji heteroskedastisitas dilakukan dengan analisis grafik plot atau nilai prediksi variabel terikat yaitu SRESID dengan residual error yaitu ZPRED. Jika tidak ada pola tertentu dan tidak menyebar di atas dan di bawah angka nol pada sumbu y, maka tidak terjadi heteroskedastisitas. Data hasil uji heteroskedatisitas di dapatkan persebaran data tidak membentuk suatu pola tertentu, sehingga dapat dikatakan bahwa data bersifat tidak heteroskedastisitas. Dengan demikian, maka data dinilai berhasil melalui uji asumsi heteroskedastisitas.

\section{Pengujian hipotesis}

Dari hasil pengujian signifikansi koefisien korelasi dan penghitungan determinasi diperoleh rhitung (ry1)sebesar 0,620 dan rhitung (ry2) sebesar 0,665. Hasil Uji-t pada taraf signifikansi $\alpha=0,05$ dengan $\mathrm{dk}$ 44 pada variabel motivasi belajar diperoleh $\mathrm{T}$ hitung 5,242 > T tabel2,02 dan variabel disiplin belajar diperoleh Thitung 5,901 > Ttabel 2,02 dan hasil analisis regresi dan korelasi ganda variabel $\mathrm{x} 1$ dan $\mathrm{x} 2$ dengan menggunakan uji $\mathrm{F}$ pada tabel ANOVA diperoleh $\mathrm{F}$ hitung = $21,105>\mathrm{F}$ tabel $=3,21$ sehingga dari data hasil pengujian dapat disimpulkan terdapat hubungan sangat signifikan antara motivasi belajar dan disiplin belajar dengan Hasil belajar hafalan $\mathrm{Al}$ Qur'an. Hasil penghitungan koefisien determinasi ganda diperoleh 49,5\% hasil belajar hafalan Al Qur'an dapat ditentukan oleh variasi motivasi belajar dan disiplin belajar, sedangkan sisanya $100 \%-49,5 \%=$ $50,5 \%$ dipengaruhi oleh variable lain di luar penelitian ini.

Berdasarkan hipotesis yang digunakan hasil di atas dapat dinyatakan bahwa terdapat hubungan positif antara Motivasi Belajar dan Disiplin Belajar dengan Hasil Belajar Hafalan Al Qur'an teruji kebenarannya. Dengan kata ain semakin tinggi motivasi belajar dan disiplin belajar siswa maka semakin tinggi Hasil Belajar Hafalan Al Qur'an yang diperoleh.

\section{Pembahasan hasil penelitian}

Kenyataan hasil di atas mengisyaratkan bahwa tinggi rendahnya hasil belajar hafalan $\mathrm{Al}$ Qur'an dapat diprediksi melalui kesesuain motivasi dan tinggi rendah disiplin belajar 
siswa baik melalui satu variabel maupun kedua variabel secara bersama. Hasil ini sejalan dengan apa yang dikemukakan oleh Rusmiasih (2013) bahwa motivasi belajar adalah kondisi psikologis yang mendorong seseorang untuk belajar. Demikian juga sejalan dengan pendapat Sardiman (2014:85-86) yang menyatakan bahwa fungsi motivasi belajar adalah sebagai pendorong usaha dan pencapaian prestasi. Sejalan pula dengan apa yang dinyatakan oleh Sanjaya (2005:9) bahwa disiplin bejalar adalah hal yang sangatlah diperlukan bagi setiap siswa. Dengan adanya disiplin belajar, tujuan pendidikan akan lebih mudah tercapai. Hasil ini juga menguatkan penelitian Penelitian yang dilakukan Titik Rahayu (2015) yang menyatakan bahwa terdapat hubungan positif yang signifikan antara kedisiplinan dengan prestasi belajar sosiologi siswa SMA Negeri 1 Teras. Dalam kaitannya dengan penelitian Nurfajari, Simanjuntak, dan Triansyah (2019) korelasi antara kedisiplinan dan motivasi dengan hasil belajar memiliki prosentase yang sangat kuat.

\section{KESIMPULAN}

Berdasarkan hasil analisis dan pembahasan yang telah diuraikan dalam penelitian ini dapat ditarik kesimpulan bahwa hasil belajar adalah salah satu indikator keberhasilan seorang siswa dari proses belajar yang dilakukakannya. Hasil belajar hafalan $\mathrm{Al}$ Qur'an siswa ada hubungannya dengan motivasi dan disiplin belajar yang dimiliki oleh siswa dalam belajar. Upaya untuk meningkatkan hasil belajar hafalan Al Qur'an diperlukan adanya kesesuain motivasi dan tingginya disiplin belajar siswa. Siswa yang memiliki motivasi dan disiplin belajar yang tinggi akan lebih mudah dalam mencapai tujuan belajarnya. Berdasarkan hasil uji hipotesis yang diperoleh dalam penelitian ini, yaitu ketiga hipotesis yang diuji memberikan hasil yang signifikan. Maka kesimpulan dalam penelitian ini dapat ditindaklanjuti dengan implikasi hasil penelitian (1) adanya hubungan yang sangat signifikan antara hafalan dengan belajar maka sebagai pendidik hendaknya dapat membangun motivasi siswa, menyediakan media dan fasilitas belajar yang dapat mendukung siswa untuk termotivasi baik dari media elektronik maupun majalah dinding, dan kata kata motivasi yang dapat diakses oleh siswa dengan mudah. Lembaga pendidikan dapat memberikan pelatihan kepada para pendidik tentang bagaimana cara memberikan motivasi atau mengggunakan alat peraga yang sesuai dengan kebutuhan siswa dalam setiap pelajaran yang diampu, mensosialisasikan tujuan pembelajaran yang akan dicapai siswa secara berkala baik kepada siswa maupun kepada orangtua, (2) selalu berupaya untuk meningkatkan disiplin siswa dengan adanya keteladanan dari dewan pendidik, ketegasan dalam menerapkan peraturan yang sudah ada, memberikan penghargaan kepada siswa yang berhasil, memberikan pembinaan berkala kepada siswa yang belum disiplin dan pembinaan kepada wali murid apabila diperlukan, dan (3) Berdasarkan data empirik dari penelitian ini bahwa secara bersama motivasi dan disiplin belajar memiliki hubungan yang kuat dengan hasil belajar. Dengan demikian siswa yang memiliki motivasi dan disiplin tinggi dapat diberikan tugas dan tanggungjawab yang lebih agar dapat menyelesaikan tugas belajarnya lebih awal. Sebagai Pendidik agar selalu dapat menjaga kestabilan motivasi dan disiplin siswa dengan memberikan reward baik verbal maupun non verbal. Sekolah dapat menyiapkan program percepatan atau akselarasi yang berkesesuaian dengan motivasi dan tinggi rendahnya disiplin siswa agar siswa merasa lebih tertantang untuk mencapai tujuan belajarnya lebih awal, dan membuat program pembinaan berkelanjutan kepada siswa yang sudah hafal untuk menjaga (maintenance) hafalan yang sudah dimiliki agar tidak lupa atau dilupakan untuk dapat digunakan kapanpun diperlukan.

Berdasarkan hasil penelitian dan kesimpulan yang telah diuraikan di atas, maka dapat dikemukakan saran-saran untuk perbaikan sebagai berikut: (1) Pemberian semangat belajar, motivasi belajar harus selalu diberikan setiap pembelajaran dilakukan. Setelah memiliki motivasi agar pendidik dapat melakukan kontrol terhadap kedisiplinan siswa. Hal ini agar motivasi belajar selalu ada pada diri setiap siswa dan bisa meningkat, (2) Pendidik harus senantiasa tegas dalam menerapkan disiplin belajar dengan memberikan teladan terkait kedisiplinan dan selalu mengingatkan siswa untuk menerapkan kedisiplinan agar sikap disiplin yang telah dimiliki siswa dapat di pertahankan dan dikembangkan ke hal atau pembelajaran lainnya, (3) Hendaknya siswa mampu memotivasi dirinya dalam belajar, 
mengetahui kemampuan dan tingkat pemahaman terhadap materi pembelajaran yang di dapat sehingga bisa menemukan solusi agar nilai hasil belajar bisa meningkat, (4) Dalam upaya menumbuhkan motivasi belajar dan disiplin belajar siswa, sebaiknya di berikan reward bagi yang berhasil dan senantiasa mentaati peraturan serta memberikan punishment mendidik bagi yang melanggar, (5) Pendidik harus senantiasa bisa menjaga dan meningkatkan kestabilan motivasi dan disiplin belajar siswa, dengan melakukan hal hal yang dapat memberikan gambaran sukses orangorang yang memiliki motivas dan sikap disiplin yang tinggi dalam usaha belajar mereka. Sebagai contoh, sampaikanlah kepada mereka kisah kisah inspiratif dengan bahasa mereka, pembelajaran di luar kelas atau sekolah dengan tetap menerapkan peraturan kedisiplinan yang sudah disepakati antara siswa dan pendidik. Jangan berikan ruang untuk siswa ataupun pendidik untuk mengabaikan atau pilih kasih dalam menerapkannya, dan (6) Bagi peneliti lain, dapat dilakukan penelitian tentang faktor penyebab yang membuat nilai hasil belajar siswa tidak maksimal selain motivasi dan disiplin belajar, sehingga dapat diketahui pengaruh yang berasal dari faktor-faktor lain yang mungkin bisa mempengaruhi hasil belajar tersebut.

\section{UCAPAN TERIMA KASIH}

Terimakasih kepada, Dr. Suryadi Naomi M.Pd, Ketua Program Magister Teknolgi Pendidkan dan Dr. Iswan, M.Si Dekan Fakultas Ilmu Pendidikan Universitas Muhammadiyah Jakarta (FIP UMJ) yang telah mendukung penelitian ini.

\section{REFERENSI}

Al Qur'an dan terjemahan. (2017). Kementerian Agama Republik Indonesia. Jakarta

Anshori. (2013). Ulumul Quran. Jakarta: Rajawali Press

As Shobuuni, Muhammad Ali. (1985). At Tibyan fi Ulumil Qur'an. Beirut: Binayatul Iman

Ash Shiddieqy, T.M.H. (2002). Sejarah dan Pengantar Ilmu Al-Qur"an dan Tafsir. Semarang: PT Pustaka Rizki Putra
Dimyati dan Mudjiono. (2006). Belajar dan Pembelajaran. Jakarta: Rineka Cipta.

Endang, Mulyatiningsih. (2011). Metode Penelitian Terapan Bidang Pendidikan. Yogyakarta: Alfabeta

Ghozali, Imam. (2018). Aplikasi Analisis Multivariate dengan Program IBM SPSS 19. Semarang: Badan Penerbit Universitas Diponegoro.

Hamalik, Oemar. (2003). Proses Belajar Mengajar. Jakarta: Bumi Aksara

Katsir, Ibnu. (2005). Tafsirul Qur'an Al Adziem. Al Qohiroh: Darul Hadist

Kathryn, R.W and Jere E. Brophy. (2014). Motivating Students to Learning. New York: Routledge.

KBBI. (2016). Badan Pengembangan dan Pembinaan Bahasa Kementerian Pendidikan dan Kebudayaan Republik Indonesia Versi: 3.5.1.120201226171802

Oxford Advanced Learner's Dictionary 2000 JM Patel College Bhandara. India.

Prijodarminto, Soegeng. (1993). Disiplin Kiat Menuju Sukses. Pradnya Paramita: Jakarta

Rusmiasih. (2013). Pengaruh Motivasi dan Disiplin belajar Terhadap Hasil Belajar Ekonomi Siswa Kelas XI IPS di SMA N 10 Purworejo, [S.1.], v. 2, n. 13, p.189194, 2013. di akses pada, 13 Agustus 2019.

Sardiman. (2012). Interaksi Dan Motivasi Belajar Mengajar. Jakarta: PT Raja Grafindo Persada.

Shihab, Quraish, M. (1996). Wawasan Al Qur'an. Bandung: Mizan

Shihab, Quraish, M. 2009. Tafsir al Misbah. Banten: Lentera Hati

Sudjana, Nana. (2009). Dasar-Dasar Proses Belajar Mengajar. Bandung: Sinar Baru Algesindo.

Sugiyono. (2012). Metode Penelitian Pendidikan. Pendekatan Kuantitatif, Kualitatif, dan $R$ dan D. Bandung: Alfabeta.

Sanjaya, Wina. (2005). Pembelajaran dalam Implementasi Kurikulum Berbasis 
Kompetensi. Jakarta. Kencana Prenada Media

Tưu, Tulus. (2008). Peran Disiplin Pada Perilaku dan Prestasi Belajar. Jakarta: Grasindo.

Undang- Undang Republik Indonesia No 20 tahun (2003) tentang Sistem Pendidikan Nasional. Jakarta: Depdiknas.
Uno, H. dan Sofyan. (2012). Teori Motivasi dan Penerapannya Dalam Penelitian. Yogyakarta: UNY Press.

Yunus, Mahmud. (1989). Kamus Arab Indonesia. Jakarta: Hidayakarya Agung Muslimin 